\title{
Nectar defense and hydrogen peroxide in floral nectar of Cucurbita pepo
}

\author{
Daniele Nocentini*, Massimo Guarnieri, Chiara Soligo \\ Department of Life Sciences, University of Siena, Via P.A. Mattioli 4, 53100 Siena, Italy
}

\begin{abstract}
This study was carried out to investigate some similarities between the nectaries of Nicotiana sp. and Cucurbita pepo, such as starch accumulation in the nectary parenchyma, changes in nectary color during maturation, and the production of a large quantity of sucrose-dominant nectar. The concentration of hydrogen peroxide in C. pepo floral nectar was determined in order to verify the presence of a defense mechanism similar to that found in Nicotiana sp. which protects nectar from yeast and bacteria proliferation. We also tested the eventual accumulation of antioxidants in the nectary of $C$. pepo as a protection against oxidative stress caused by hydrogen peroxide. The level of hydrogen peroxide found in the floral nectar of C. pepo was much lower than that found in Nicotiana sp. and the male flowers of Cucurbita had a higher concentration than the female flowers. The low oxidative stress induced by this level of hydrogen peroxide caused the accumulation of a low amount of lutein inside the plastoglobules which were contained in amyloplasts. Plastids of the C. pepo nectary are specialized in the accumulation of starch rather than antioxidants.
\end{abstract}

Keywords: nectar; nectary; plastids; hydrogen peroxide; lutein; antioxidants; nectar defense

\section{Introduction}

Predation is not the only type of interaction between animals and plants. Frequently, there is a mutual interaction between them: animals are generally rewarded with food, while plants benefit in terms of pollination, seed/fruit dispersal or defense against herbivores [1]. Nectar is a plant secretion composed mainly of water and sugars and related to both plant pollination, floral nectar being the reward for pollinators that mediate the dispersal of pollen [2], and the plant's indirect defense, extra-floral nectar being a reward for ants defending plants against predators [3].

Simple sugars are the more abundant compounds in floral nectar; their high energetic value and easy digestibility are at the basis of the alimentary importance of this resource for a large array of animals that generally perform pollination. On the other hand, this sugary secretion may host pollinator-carried microorganisms such fungi and bacteria that use the nectar as a growing medium. About half of the samples analyzed in a survey study were positive for yeast, which are responsible for alcoholic fermentation and thus modification of sugar composition [4]. Fermentation changes the sugar profile by reducing the total sugar concentration and lowering the level of sucrose [4,5]. This profound change in the chemistry of nectar may affect the plant-pollinator relationship since the sugar profile of nectar is strictly related

*Corresponding author. Email: nocentini19@unisi.it

Handling Editor: Elżbieta Weryszko-Chmielewska to pollinator preferences [6,7]. Thus, plants have to produce a sugary secretion (nectar) to attract pollinators and in the meanwhile they must avoid an excess of microorganism proliferation in the secretion. This "dilemma" was overridden by the development of complex defense systems to reduce microbial growth in nectar [8]. One of these strategies is the production of a high level of hydrogen peroxide $\left(\mathrm{H}_{2} \mathrm{O}_{2}\right)$ through a specific nectar metabolic pathway, as it was demonstrated in Nicotiana langsdorffi $\times N$. sanderae [9-12]. At the same time, nectaries need to produce antioxidants (such as carotenoids) as protection of tissues against oxidative stress due to the high level of hydrogen peroxide. In Nicotiana sp. there is a change in color during nectary development from pale green in the early stage to deep orange in the mature stage. This change in color is due to the accumulation of $\beta$-carotene as plastoglobules inside the amyloplasts of the nectary [13].

Considering several analogies in nectary development between Nicotiana sp. and Cucurbita pepo, such as starch accumulation in the nectary parenchyma, change in nectary color during flower development, and the production of a large quantity of sucrose-dominant nectar [14-16], this study wanted to investigate if nectar protection through hydrogen peroxide similar to that of the Nicotiana hybrid operates in C. pepo. Furthermore, we asked if the change in color of the floral nectary of C. pepo is due to antioxidant accumulation in the nectary plastids in analogy with the Nicotiana hybrid. Cucurbita pepo produces a copious amount of nectar in the male and female flowers that have a different nectar presentation to pollinators, since they 
are morphologically dimorphic [15-18]. This latter aspect makes the comparison of the defense systems of the two flower morphs particularly interesting. The ultrastructure of nectary development have been studied already by Nepi et al. [14] and this study revealed the crucial role of parenchyma cell plastids in the functioning of the nectary during nectar secretion and reabsorption.

\section{Material and methods}

\section{Plant material}

Cucurbita pepo L. is a monoecious entomophilous species native to Mexico [19]: in other words, it carries unisexual male and female flowers on the same plant. The nectaries are morphologically dimorphic in the two sexes, their position and accessibility to pollinators being different in the male and female flowers. In the female flowers, the nectary consists of an annular furrow around the base of the style and it is completely accessible from the top (Fig. 1). The male flowers have a nectary chamber closed inside the fused base of the anther filaments ad it is accessible only through two-three small pores (the diameter ranging 1.0-2.5 mm; Fig. 1). Cucurbita pepo plants (cultivar 'Nero di Milano') used for this study were cultivated in the open air in the Botanical Garden of the Siena University from June to August 2010.

\section{Nectar sampling and detection of hydrogen peroxide}

Eight male and eight female flowers from twelve different plants were bagged with tulle nets (mesh $1.0 \mathrm{~mm}$ $\varnothing)$ to exclude pollinator visits and allowing the nectar to accumulate. Nectar was sampled by using graduated glass capillaries and the volume of each sample was determined. After collection, the samples were immediately subjected to the determination of hydrogen peroxide. We used an assay based on the FOX reagent [20,21]. The content of hydrogen peroxide in the nectar was identified photometrically, using a UV-visible Shimadzu UV160 spectrophotometer $(\lambda=$ $560 \mathrm{~nm}$ ). The calibration curve was performed by using standard solutions of hydrogen peroxide with a concentration ranging from 0 to $1 \mathrm{mM}$.

The differences in the concentration of hydrogen peroxide between the sexes were tested for significance by the nonparametric Mann-Whitney U test $(\alpha=0.05)$, since the data were not normally distributed. The statistics were performed using the program Statistica (ver. 7.1, StatSoft).

\section{Determination of nectary pigments}

Samples of nectaries were dissected from 3 male flowers for each of 4 different stages of development (Fig. 2):

(i) stage 1: 5 days before anthesis (length of the flower bud was 30-35 mm, nectary white);

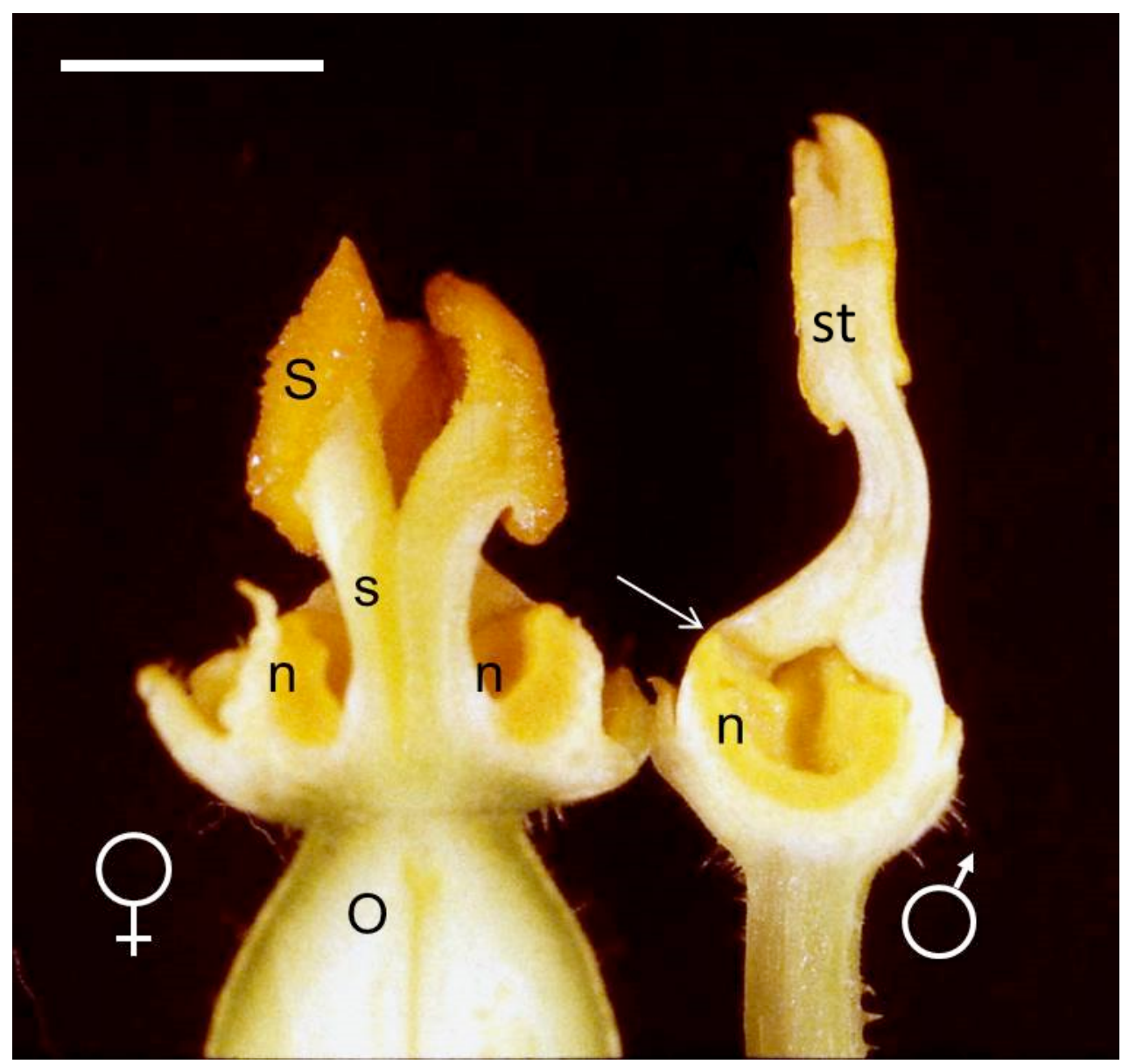

Fig. 1 Longitudinal section of female and male flowers showing the different position and accessibility of the nectary. In the female (P) flower, the nectary forms a furrow around the base of the style and it is completely accessible from above. In the male ( $\left({ }^{\lambda}\right)$ flowers, the nectary is a cavity inside the fused base of the anther filaments and it is accessible only trough 2-3 pores. $\mathrm{n}$ - nectary; O - ovary; $\mathrm{S}$ - stigma; s - style; st - stamens. Scale bar: $1 \mathrm{~cm}$. 
(ii) stage 2: 4 days before anthesis (length of the flower bud was $40-45 \mathrm{~mm}$, nectary white);

(iii) stage 3: 2 days before anthesis (length of the flower bud was 60-65 mm, nectary pale yellow);

(iv) stage 4: 1 day before anthesis (length of the flower bud was $75-80 \mathrm{~mm}$, nectary yellow).

The weight of each sample was recorded. $500 \mu \mathrm{l}$ of dimethylformamide (DMF) were added to each sample. Then, they were homogenized for 60 seconds with Ultra Turrax. Afterwards, the homogenized samples were centrifuged at 13000 r.c.f. $(g)$ for 5 minutes. The supernatant was analyzed by reverse-phase HPLC (high performance liquid chromatography) according to Suzuki et al. [22] using a Waters LC1 system. Chromatographic peaks were identified by running the following standards: chlorophyll $a\left(10 \mu \mathrm{g} \mathrm{ml}^{-1}\right)$, chlorophyll $b\left(10 \mu \mathrm{g} \mathrm{ml}^{-1}\right)$, lutein $\left(10 \mu \mathrm{g} \mathrm{ml}^{-1}\right), \beta$-carotene $\left(50 \mu \mathrm{g} \mathrm{ml}^{-1}\right)$. The pigments were detected by a UV-visible detector $(\lambda=440 \mathrm{~nm})$.

\section{Transmission electron microscopy for plastid development}

In order to assess plastid development, small fragments of nectariferous tissue from the different male flower stages (1-4; see above) were processed as follows:

(i) fixation in $3 \%$ glutaraldehyde in $0.06 \mathrm{M}$ cacodylate buffer for 2 hours;

(ii) postfixation in $1 \%$ osmium tetroxide for 1 hour;

(iii) dehydration in an ethanol series; (iv) embedding in Spurr low viscosity resin;

(v) cutting with an LKB III ultramicrotome;

(vi) staining with uranyl acetate and lead citrate.

The sections were finally observed through a Philips Morgagni 268D Transmission Electron. Microscope (TEM) equipped with a digital camera.

\section{Results}

Hydrogen peroxide in male and female nectar samples

The concentration of hydrogen peroxide in the nectar from the male flowers was about $0.10 \mathrm{mM}$. In the female flowers, the concentration of hydrogen peroxide was about fourfold less (Fig. 3). The differences between the sexes were significant (Mann-Whitney $\mathrm{U}$ test $Z=2.559 ; P=0.0104$ ).

\section{Photosynthetic pigments during nectary development in male flowers}

The floral nectary development consists in a number of different stages. At least four were here characterized by the changes in shape, dimension and color, from greenish-white to yellow (Fig. 2). The determination of photosynthetic pigments in the $C$. pepo nectary demonstrated the complete absence of $\beta$-carotene and chlorophyll $a$ and $b$ in all the flower stages (1-4). HPLC analysis led to the determination of lutein in an amount of $4 \mathrm{ng} / \mathrm{mg}$ only in stage 4.

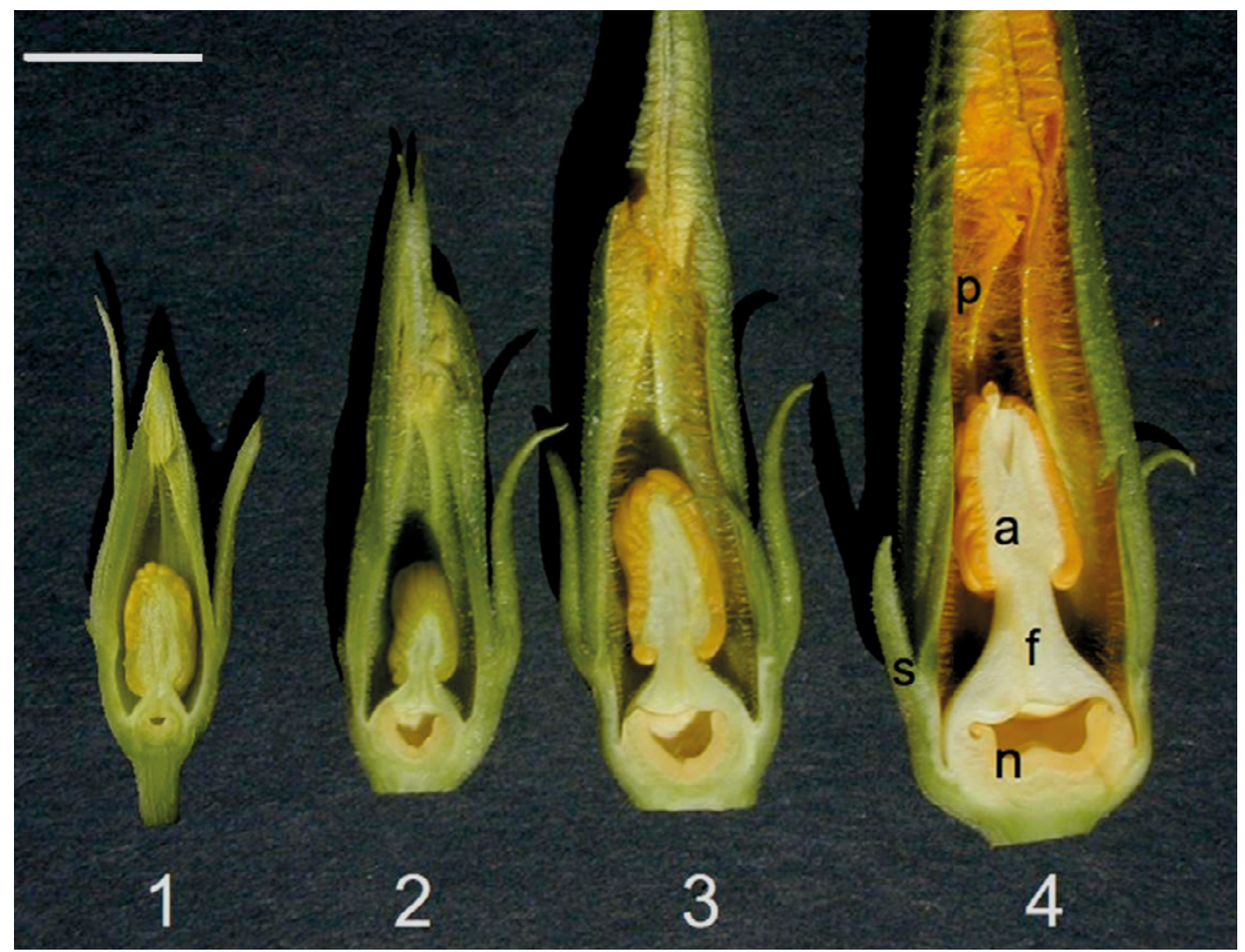

Fig. 2 Longitudinal sections of male flowers at different developmental stages. The nectary color turns from white-greenish (stage 1) to yellow (stage 4). a - fused anthers; $\mathrm{f}$ - fused filaments; $\mathrm{n}$ - nectary; $\mathrm{p}$ - petal; $\mathrm{s}$ - sepal. Scale bar $=1 \mathrm{~cm}$. 


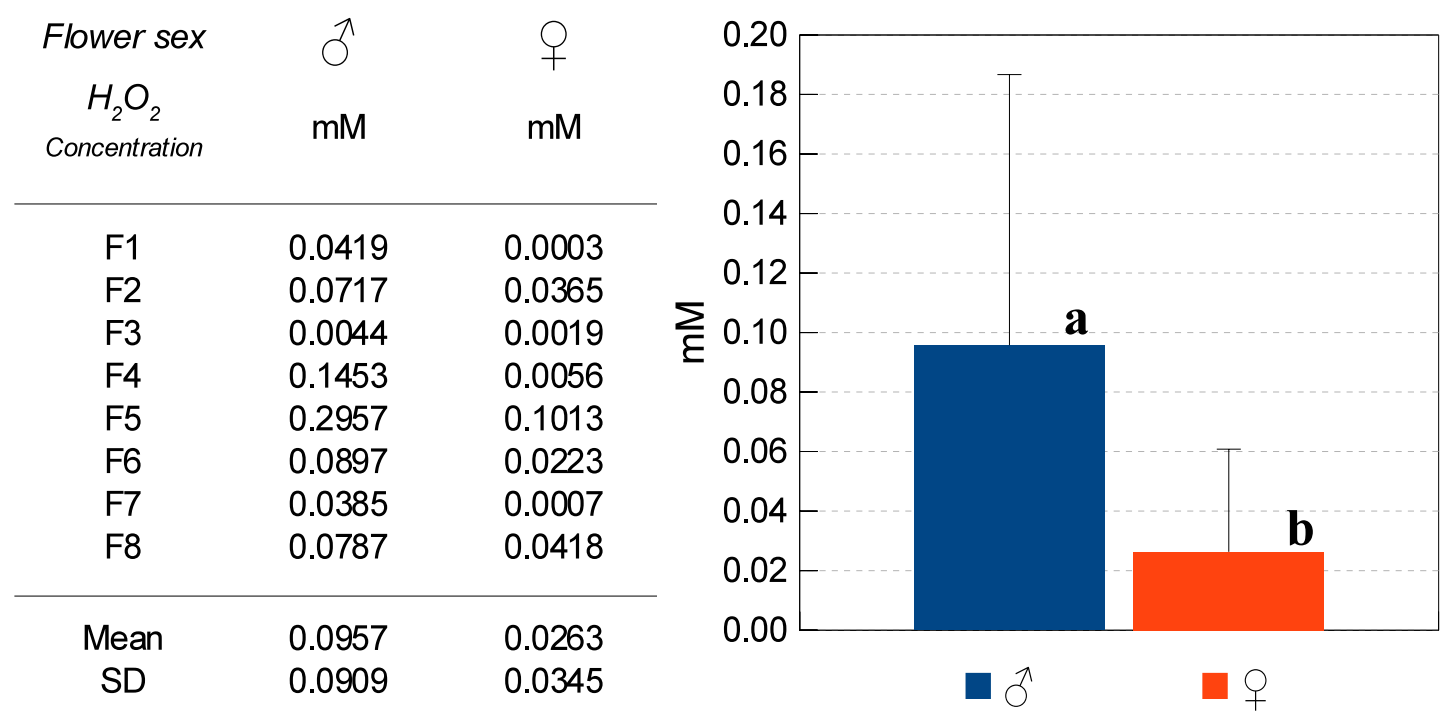

Fig. 3 Hydrogen peroxide concentrations found in nectar from 8 male and 8 female flowers. Nectar from the male flowers contained more hydrogen peroxide than that from the female flowers. Different letters indicate statistically significant differences according to Mann-Whitney U test $(Z=2.559 ; P=0.0104)$.

\section{Plastids during nectary development}

In the flowers of stage 1, plastids of the nectary parenchyma cells had generally elongated and irregular shapes (Fig. 4a,b). The internal system of membranes was poorly represented with tubular and vesicular structures (Fig. 4b). The abundant stroma appear granular and relatively homogeneous. Each plastid contains few starch grains with a rounded shape. The nectary plastids in the flowers at stage 2 appear very similar to the previous stage, but they contain a higher number of rounded starch grains (not shown in Fig. 4). At stage 3 , the plastids of the nectary parenchyma cells appeared less elongated with much more starch grains, some of them have a polygonal shape (Fig. 4c,d). Few internal membranes were present, and they partially surrounded the larger starch grains (Fig. 4d). The stroma was less abundant than in the previous stages and it is still granular and homogeneous. In the flowers at stage 4, plastids were more or less spherical with a lot of starch grains tightly packed and with very few stroma between them (Fig. 4e,f). In some plastids, few dark plastoglobules are present and frequently associated with the internal membranes (Fig. 4f).

\section{Discussion}

The presence of yeasts and bacteria in floral nectar was recently highlighted $[4,23]$ and it can be deleterious for plants mainly for two reasons: (i) some of these microorganisms can be phytopathogens and also responsible for the infection of plant tissues [24]; (ii) they use nectar as a growing medium altering the content of sugars and amino acids and thus competing with pollinators for this alimentary resource [25]. To counteract the potentially negative impact of nectardwelling microorganisms, plants evolved defense systems that are mainly based on secondary compounds (such as tannins, phenolics and alkaloids) and proteins. Five specific proteins (named Nec 1-5) that function in defense against fungi and bacteria were the only proteins found in the floral nectar of Nicotiana langsdorffi $\times N$. sanderae, ornamental tobacco [10-12]. They form a new metabolic pathway that is called the nectar redox cycle (NRC) and serves to maintain high concentrations of hydrogen peroxide that protect the nectary from microorganism growth $[11,12,26]$. Carter and Thornburg [11], after examining the presence of $\mathrm{Nec} 1$ homologues in 15 unrelated plant species, concluded that most probably NRC is widespread in angiosperms.

Plants anyway may possess a plethora of other proteins with antimicrobial activity in their floral nectar [8]. In the floral nectar of C. pepo, 24 and 17 protein spots were separated by $2 \mathrm{D}$ electrophoresis in the female and male flowers, respectively, and four major proteins present in both nectars were identified as xylosidases with putative antimicrobial activity [8]. The results of the present study suggest a contribution of hydrogen peroxide, and eventually of NRC, in the defense system of $C$. pepo nectar, as well.

Concentrations of hydrogen peroxide up to $4 \mathrm{mM}$ were found in the Nicotiana hybrid [11], a level that is 40 -fold higher than that produced by human neutrophils when they engulf and destroy invading microorganisms [27]. The concentration of hydrogen peroxide found in the floral nectar of $C$. pepo was always much lower. The maximum value of hydrogen peroxide found in the nectar from the male and female flowers of C. pepo was $0.29 \mathrm{mM}$ and $0.10 \mathrm{mM}$, respectively. These values are similar to the concentration of hydrogen peroxide produced by human neutrophils (about $0.1 \mathrm{mM}$ ) in response to microbial attack [27]. Thus, we can reasonably suppose that hydrogen peroxide found in C. pepo nectar can be active against microbial growth, although the concentration in some flowers is much lower than that found for Nicotiana. The high variability of hydrogen peroxide concentration in floral nectar that we found can be due to differences in the expression of genes related to 

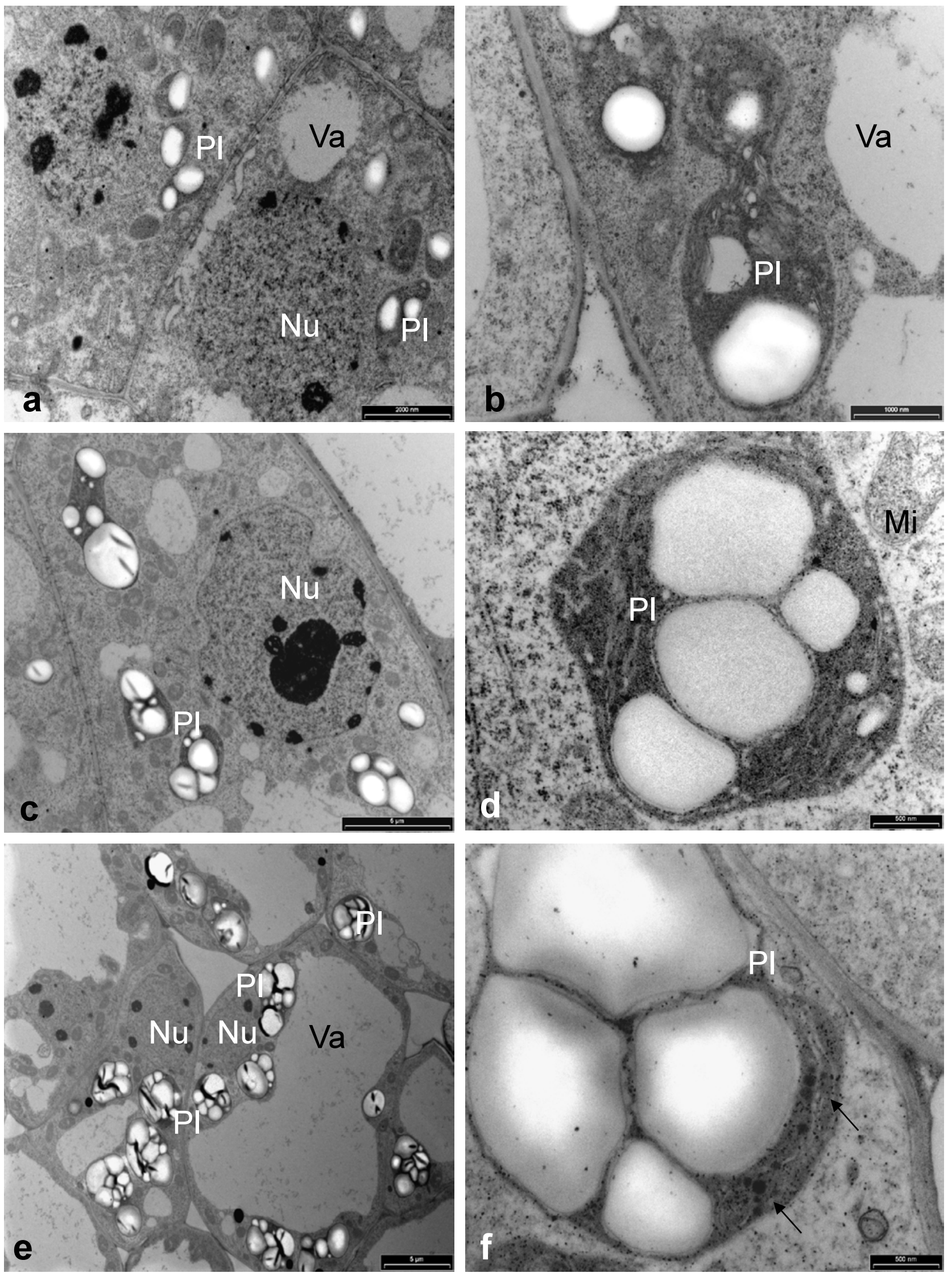

Fig. 4 Plastids during nectary development (stage 1-4) in the male flowers of Cucurbita pepo. In stage 1 (a,b), plastids have an irregular shape, few (1-2) starch grains and a dark, granular and relatively homogeneous stroma. Sometimes plastids are dividing (b). In stage 3 $(\mathbf{c}, \mathbf{d})$ plastids contain more numerous and larger starch grains and have a less abundant stroma that is still granular and homogeneous. In stage $4(\mathbf{e}, \mathbf{f})$ most plastids have a rounded shape and contain many starch grains with a polygonal contour. The stroma is very reduced. Some dark plastoglobules (arrows) are associated with the internal membranes. Mi - mitochondrion; $\mathrm{Nu}$ - nucleus; $\mathrm{Pl}$ - plastid; Va vacuole. Scale bar: $2 \mu \mathrm{m}(\mathbf{a}) ; 1 \mu \mathrm{m}(\mathbf{b}) ; 5 \mu \mathrm{m}(\mathbf{c}, \mathbf{e}) ; 0.5 \mu \mathrm{m}(\mathbf{d}, \mathbf{f})$. 
the production of this substance or alternatively to different densities of microorganism cells in the nectar. In fact, it is known that the inoculation of nectar with Gluconobacter (bacterium) and Metschnikowia reukaufii (yeast) resulted in a sharp decrease in hydrogen peroxide concentration [28]. In this regard, it must be said that we determined the hydrogen peroxide concentration in bagged flowers not exposed to the visits of pollinators that are generally considered the main vector of nectar-inhabiting microorganisms [5,23]. Nonetheless, it is to consider that airborne contamination of nectar is also possible [29].

We found that the male flowers of $C$. pepo contained significantly more hydrogen peroxide than the female ones. This difference can be related to the different exposure of the two dimorphic nectaries (and thus nectar) to the external environment (Fig. 1). Considering the flower morphology, female flowers are potentially more exposed to contamination by microorganisms that may lower the hydrogen peroxide concentration. In this respect, it is interesting to note that female nectar of $C$. pepo has a wider spectrum of defense proteins than male nectar [8], probably because it needs more protection.

The high levels of hydrogen peroxide found in N. langsdorffii $\times N$. sanderae nectar results in a highly oxidative environment and thus strong oxidative stress in the nectary tissues. Consequently, the nectary produces antioxidants as protection against this stressful condition. The strong change in the color of the nectary tissue from young to mature stage is very evident in Nicotiana, from pale yellow to deep orange, and it is due to the accumulation of $\beta$-carotene as evidenced by numerous plastoglobules inside the majority of plastids (see Fig. 9 in [13]). Referring to the anti-oxidant

\section{Acknowledgments}

The authors are grateful to the personnel of the Botanical Garden of the University of Siena (Siena, Italy) for cultivating the plants used in this study. The authors thank Mrs. Claudia Faleri (University of Siena, Department of Life Sciences) for technical assistance during TEM observations. This research was funded by PAR 2008 (Piano di Ateneo per la Ricerca, University of Siena).

\section{Authors' contributions}

The following declarations about authors' contributions to the research have been made: set up the experimental design, performed the hydrogen peroxide determinations and wrote the manuscript: DN; performed nectar and nectary sampling and the microscopic observations: CS; carried out the HPLC analysis of nectary pigments: MG.

\section{Competing interests}

No competing interests have been declared.

\section{References}

1. Pacini E, Viegi L, Franchi GG. Types, evolution and significance of plant-animal interactions. Rendiconti Lincei. 2008;19:75-101. http:// dx.doi.org/10.1007/s12210-008-0005-9

2. Faegri K, van der Pjil L. The principles of pollination ecology. 3rd ed. Oxford: Pergamon Press; 1979.

3. Heil M, 2008. Indirect defense-via tritrophic interactions. New Phytol. 2008;78:41-61. http://dx.doi.org/10.1111/j.1469-8137.2007.02330.x

4. Herrera CM, de Vega C, Canto A, Pozo MI. Yeasts in floral nectar: a quantitative survey. Ann Bot. 2009;103:1415-1423. http://dx.doi. org/10.1093/aob/mcp026 content, we found evident differences between Nicotiana and C. pepo. Due to the lower level of nectar hydrogen peroxide, the C. pepo nectaries experienced much lower oxidative stress. Indeed, there is only a moderate change in color from milky-green in young flowers (stage 1) to yellow in mature flowers (stage 4). The yellow color of the mature nectaries is due to the presence of lutein (up to $4 \mathrm{ng} \mathrm{mg}^{-1}$ ), a carotenoid with antioxidant activity that was detected only in the mature stage. The low lutein content of the mature nectary resulted in the presence of rare plastoglobules inside plastids.

\section{Conclusions}

Floral nectar of $C$. pepo contains a much lower concentration of hydrogen peroxide than that of Nicotiana langsdorffi $\times N$. sanderae. Nectar from the male flowers has a higher concentration of hydrogen peroxide than that from the female flowers. There is high between-flower variability and the higher concentrations can be active against microbial proliferation. The low level of oxidative stress induced by hydrogen peroxide at the concentration we found in the nectar of $C$. pepo is counterweighted by the accumulation of a low amount of lutein in the few plastoglobules of amyloplasts evident only in the mature floral stage. While the nectary plastids of the Nicotiana hybrid accumulate starch and pigments ( $\beta$-carotene) and for this reason are called chromo-amyloplasts, the plastids of the nectary of C. pepo are more specialized in starch storage and their accumulation of antioxidant pigments is very moderate.

5. Canto A, Herrera CM, García IM, Pérez R, Vaz M. Intraplant variation in nectar traits in Helleborus foetidus (Ranunculaceae) as related to floral phase, environmental conditions and pollinator exposure. Flora. 2011;206:668-675. http://dx.doi.org/10.1016/j.flora.2011.02.003

6. Baker HG, Baker I. Chemical constituents of nectar in relation to pollination mechanism and phylogeny. In: Nitecki MH, editor. Biochemical aspects of evolutionary biology. Chicago, IL: University of Chicago Press; 1982. p. 131-171.

7. Raguso RA. Why are some floral nectar scented? Ecology. 2004;85:1486-1494. http://dx.doi.org/10.1890/03-0410

8. Nepi M, Bini L, Puglia M, Cai G. Xylan degrading enzymes in male and female flower nectar of Cucurbita pepo. Ann Bot. 2011;108:521-527. http://dx.doi.org/10.1093/aob/mcr165

9. Carter C, Graham R, Thornburg RW. Nectarin I is a novel, soluble germin-like protein expressed in the nectar of Nicotiana sp. Plant Mol Biol. 1999;41:201-216. http://dx.doi.org/10.1023/A:1006363508648

10. Carter C, Healy R, O'Tool NM, Naqvi SM, Ren G, Park S, et al. Tobacco nectaries express a novel NADPH oxidase implicated in the defense of floral reproductive tissues against microorganism. Plant Physiol. 2007;143:389-399. http://dx.doi.org/10.1104/pp.106.089326

11. Carter C, Thornburg RW. Tobacco Nectarin I: purification and characterization as a germin-like, manganese superoxide dismutase implicated in the defense of floral reproductive tissues. J Biol Chem. 2000;275:36726-36733. http://dx.doi.org/10.1074/jbc.M006461200

12. Carter C, Thornburg RW. Is the nectar redox cycle a floral defense against microbial attack? Trends Plant Sci. 2004;9:320-324. http:// dx.doi.org/10.1016/j.tplants.2004.05.008

13. Horner HT, Healy RA, Ren G, Klyne A, Seames C, Thornburg RW. 
Amyloplast to chromoplast conversion in developing ornamental tobacco floral nectaries provides sugar for nectar and antioxidants for protection. Am J Bot. 2007;94:12-24. http://dx.doi.org/10.3732/ ajb.94.1.12

14. Nepi M, Ciampolini F, Pacini E. Development of Cucurbita pepo nectaries of male flowers. Ann Bot. 1996;78:95-104. http://dx.doi. org/10.1006/anbo.1996.0100

15. Nepi M, Guarnieri M, Pacini E. Nectar secretion, reabsorption, and sugar composition in male and female flowers of Cucurbita pepo. Int J Plant Sci. 2001;162:353-358. http://dx.doi.org/10.1086/319581

16. Dmitruk M. Flowering biology, nectar production and insect visits in Cucurbita pepo L. flowers. Acta Agrobot. 2006;59:183-197. http:// dx.doi.org/10.5586/aa.2006.019

17. Nepi M, Pacini E. Pollination, pollen viability and pistil receptivity in Cucurbita pepo. Ann Bot. 1993;72:527-536. http://dx.doi.org/10.1006/ anbo.1993.1141

18. Dmitruk M, Weryszko-Chmielewska E. The morphology and ultrastructure of the nectaries of marrow (Cucurbita pepo L. convar. giromontiina). Acta Agrobot. 2013;66:11-22. http://dx.doi.org/10.5586/ aa.2013.033

19. Whitacker TW, Bemis WP. Cucurbits: Cucumis, Citrullus, Cucurbita, Lagenaria (Cucurbitaceae). In: Simmonds NW, editor. Evolution of crop plants. London: Longman; 1976. p. 243-257.

20. Bleau G, Gaisson C, Brunette I. Measurement of hydrogen peroxide in biological samples containing high levels of ascorbic acid. Anal Biochem. 1998;263:13-17. http://dx.doi.org/10.1006/abio.1998.2801

21. Gay CA, Gebicki J, 2002. Perchloric acid enhances sensitivity and reproducibility of the ferric-xylenol orange peroxide assays. Anal Biochem. 2002;304:42-46. http://dx.doi.org/10.1006/abio.2001.5566

22. Suzuki R, Takahashi M, Furuya K, Ishimaru T. Simplified technique for the rapid determination of Phytoplankton pigments by reverse-phase High-Performance-Chromatography. J Oceanogr. 1993;49:571-580. http://dx.doi.org/10.1007/BF02237463

23. Herrera CM, Garcìa IM, Pérez R. Invisible floral larcenies: microbial communities degrade floral nectar of bumble bee-pollinated plants. Ecology. 2008;89:2369-2376. http://dx.doi.org/10.1890/08-0241.1

24. Sasu MA, Seidl-Adams I, Wall K, Winsor JA, Stephenson AG. Floral transmission of Erwinia tracheiphila by cucumber beetles in a wild Cucurbita pepo. Environ Entomol. 2010;39:140-148. http://dx.doi. org/10.1603/EN09190
25. Nepi M. Nectar: plant interface for complex interaction with biotic environment. In: Ramawat KG, Mérillon JM, Shivanna KR, editors. Reproductive biology of plants. Boca Raton, FL: CRC Press; 2014. p. 268-283. http://dx.doi.org/10.1201/b16535-13

26. Nicolson SW, Thornburg RW. Nectar chemistry. In: Nicolson SW, Nepi M, Pacini E, editors. Nectaries and nectar. Dordrecht: Springer; 2007. p. 215-264. http://dx.doi.org/10.1007/978-1-4020-5937-7

27. Prince RC, Gunson DE. Superoxide production in neutrophils. Trends Biochem Sci. 1987;12:86-87. http://dx.doi. org/10.1016/0968-0004(87)90041-7

28. Vannette RL, Gauthier MPL, Fukami T. Nectar bacteria, but not yeast, weaken a plant-pollinator mutualism. Proc R Soc B. 2013;280:20122601. http://dx.doi.org/10.1098/rspb.2012.2601

29. Pozo MI, Lachance MA, Herrera CM. Nectar yeasts of two southern Spanish plants: the roles of immigration and physiological traits in community assembly. FEMS Microbiol Ecol. 2012;80:281-293. http:// dx.doi.org/10.1111/j.1574-6941.2011.01286.x

\section{Mechanizm obronny oraz nadtlenek wodoru w nektarze kwiatowym Cucurbita pepo}

\section{Streszczenie}

Przedstawiona praca miała na celu zbadanie niektórych podobieństw pomiędzy nektarnikami Nicotiana sp. i Cucurbita pepo, takich jak gromadzenie skrobi w parenchymie nektarnika, zmiany w kolorze nektarnika w trakcie dojrzewania oraz wytwarzanie dużej ilości nektaru z sacharozą jako cukrem dominującym. Określono stężenie nadtlenku wodoru w nektarze kwiatowym C. pepo w celu sprawdzenia obecności mechanizmu obronnego podobnego do mechanizmu stwierdzonego u Nicotiana sp., który chroni nektar przed rozmnażaniem się drożdży i bakterii. Zbadaliśmy także akumulację przeciwutleniaczy w nektarniku C. pepo jako ochronę przeciwko stresowi oksydacyjnemu spowodowanemu przez nadtlenek wodoru. Poziom nadtlenku wodoru stwierdzony w nektarze kwiatowym C. pepo był o wiele niższy niż u Nicotiana sp., a kwiaty męskie Cucurbita wykazywały wyższe stężenie tego związku niż kwiaty żeńskie. Niewielki stres oksydacyjny wywołany przez ten poziom nadtlenku wodoru powodował gromadzenie się niewielkiej ilości luteiny wewnątrz plastoglobuli, które znajdowały się w amyloplastach. Plastydy nektarnika C. pepo są wyspecjalizowane raczej w gromadzeniu skrobi niż przeciwutleniaczy. 